Japan. J. Breed. $39: 319 \sim 325$ (1989)

\title{
Utilization of Resistant Cell Lines to 5-methyltryptophan for Cell Fusion in Rice (Oryza sativa L.)
}

\author{
Hyo-yon LeE and Toshiaki KameYA \\ Institute of Genetic Ecology, Tohoku University, Sendai, 980
}

\begin{abstract}
5-methyltryptophan (5MT) resistant cell lines, SAR-1, SAR-2 and SAR-3 were selected from anther derived calli of rice (Oryza sativa L. var Sasanishiki). Among these selected cell lines, two (SAR-1 and SAR-3) were stable in 5MT resistance and accumulated free tryprophan at least 50 times higher than that of the unselected cells. The resistant cell lines, however, were not able to produce plants on regeneration medium. Protoplasts from SAR-3 suspension culture cells were fused using dextran method with protoplasts of 5MT sensitive cells (Oryza sativa L. var. Hanahikari) which had the ability to regenerate plants. Prospective somatic hybrids were selected by culture on selection medium contianing 5MT and then on regeneration medium for plant formation. Three albino plants suspected to be somatic hybrids were regenerated from selected colonies. Calli, initiated from the plants, showed resistance to 5MT intermediate between that of the two parents. These results indicate that the combinaion of 5MT resistance and plant regeneration ability can be used as a complementary marker for selection and identification of somatic hybrids in rice plants.

KEY WORDS: Oryza sativa L., cell culture, 5MT resistance, protoplast fusion, somatic hybrid.
\end{abstract}

\section{Introduction}

During the last decade, many somatic hybrids were obtained through protoplast fusion. These somatic hybrids were produced using selection systems, such as biochemical markers, which allowed easy identification of hybrids on a suitable medium. Of the biochemical mutants, amino acid analog-resistance has been shown to be useful as a dominant selection marker in selecting somatic hybrids (White and Vasil 1979, Harms et al. 1981, 1982, KameYa et al. 1981, Horn et al. 1983, Toriyama et al. 1987).

Recently, plant regeneration has been reported from rice protoplasts isolated from cultured cells, that should be a prerequisite for the utilization of somatic hybridization (AbDullaH 1986).

In this paper, we deal with selection and characterization of 5MT resistant cell lines of rice, which could not form plants on the regeneration medium. We also report that somatic hybrids were successfully obtained by fusing the 5MT resistant cell line with a different cultivar having plant regeneration ability.

\section{Materials and Methods}

\section{Plant materials}

Calli used in this study were initiated from anther culture of rice (Oryza sativa L. var. Sasanishiki). The anthers containing uninuclate pollen grains were placed on each of B5 (Gamborg et al. 1968), AA (Toriyama and Hinata 1985) and N6 (Chu et al. 1975) agar (0.8\%) medium supplemented with $2 \mathrm{mg} / \ell$ of 2,4 -dichlorophenoxy acetic acid $(2,4-\mathrm{D})$ to induce callus 
formation. The anther-derived calli were transferred to $40 \mathrm{~m} \ell$ of AA medium, and cultured in $100 \mathrm{~m} \ell$ flasks with reciprocal shaking at $120 \mathrm{rev} / \mathrm{min}$. to establish suspension cultures. The cultures were grwon in the dark at $25^{\circ} \mathrm{C}$ and subcultured every 2 weeks at a $1: 4$ dilution rate (suspension inoculum/fresh medium).

\section{Selection of $5 M T$ resistant cells}

Six month-old subcultured cells were passed through a $200 \mu \mathrm{m}$-mesh nylon net and about two hundred $\mathrm{mg}$ fresh weight of them were transferred to $40 \mathrm{~m} \ell$ of AA liquid medium containing $50 \mathrm{ppm} 5 \mathrm{MT}$. After 4 to 5 weeks, rapidly growing cells were plated on AA agar $(0.8 \%)$ medium containing $50 \mathrm{ppm} 5 \mathrm{MT}$ in a Petri dish $(90 \mathrm{~mm}$ diameter, $15 \mathrm{~mm}$ hight $)$ and cultured under diffuse light (3000 lux) at $25^{\circ} \mathrm{C}$.

\section{Test for $5 M T$ resistance}

Resistance to $5 \mathrm{MT}$ was tested by inoculating $200 \mathrm{mg}$ fresh weight of cells into $40 \mathrm{~m} \ell$ of AA medium having different concentrations of 5MT. The growth was measured by the settled-cell volume after 10 days.

\section{Analysis of free amino acid}

Free amino acids were extracted from 12-day-old suspension cells cultured in AA liquid medium according to the method of WAKASA and WIDHOLM (1987) and analysed with an automatic amino acid analyzer, HITACHI 835-50.

Table 1. Free amino acid contents of unselected cell (SAS) and 5MT-resistant cell (SAR-3) Numbers are given as $\mathrm{n} \mathrm{mol} / \mathrm{gFW}$

\begin{tabular}{lrc}
\hline Amino acid & unselected cell (SAS) & Resistant cell (SAR-3) \\
\hline ASP & 51.07 & 254.46 \\
THR & 104.72 & 166.90 \\
SER & 136.12 & 282.11 \\
GLU & 155.93 & 714.80 \\
GLY & 251.67 & 625.80 \\
ALA & 361.65 & 712.48 \\
CYS & 78.39 & 134.64 \\
VAL & 192.40 & 304.71 \\
MET & 54.47 & 112.31 \\
ILE & 109.90 & 168.56 \\
LEU & 167.98 & 256.42 \\
TYR & 93.32 & 133.63 \\
PHE & 87.16 & 147.97 \\
LYS & 217.03 & 208.24 \\
HIS & 66.49 & 93.82 \\
TRY & 24.34 & 1370.75 \\
ARG & 997.51 & 618.38 \\
\hline Total & 3150.15 & 6305.98 \\
\hline
\end{tabular}


Protoplast isolation, fusion, selection and culture

Protoplasts were prepared from suspension cultured cells of a 5MT-resistant cell line (SAR-3) and a 5MT-sensitive cell line, HA (Oryza sativa L. var Hanahikari) initiated form anther on AA agar medium supplemented with $2 \mathrm{mg} / \ell$ 2,4-D. A $0.5 \mathrm{~m} \ell$ (settled cell volume) of 5-dayold cells was incubated in $10 \mathrm{~m} \ell$ of an enzyme soluation consisted of $2 \%$ Cellulase Onozuka R10 (Yakult Biochemicals, Nishinomiya, Japan), $0.2 \%$ Macerozyme R10 (Yakult Biochemicals), 6.5\% mannitol and $0.1 \% \mathrm{CaCl}_{2} 2 \mathrm{H}_{2} \mathrm{O}(\mathrm{pH}$ 5.5) on a reciprocal shaker $(60 \mathrm{rev} / \mathrm{min})$ for 1.5 $\mathrm{h}$, followed by $1.5 \mathrm{~h}$ of stationary incubation at $25^{\circ} \mathrm{C}$. The protoplasts were passed through a $30 \mu \mathrm{m}$-mesh nylon net, and washed three times with a washing solution consisting of $6.5 \%$ mannitol and $0.1 \% \mathrm{CaCl}_{2} 2 \mathrm{H}_{2} \mathrm{O}$ (pH 5.5) by centrifugation $(100 \times \mathrm{g}, 3 \mathrm{~min})$.

Protoplast fusion was carried out by dextran treatment (KAMEYA 1983) after mixing equal parts of protoplasts of SAR-3 and HA. These protoplasts $(2 \times$ $10^{5} / \mathrm{m} \ell$ ) were cultured in $2 \mathrm{~m} \ell$ of B5 medium supplemented with $5 \%$ glucose. After 2 weeks, $1 \mathrm{~m} \ell$ fresh B5 medium cotaining $3 \%$ glucose was added and after another 2-3 weeks, an equal volume of AA medium containing $50 \mathrm{ppm} 5 \mathrm{MT}$ (selection medium) was added. After two weeks of culture in the selection medium, the cell colonies were transferred onto B5 agar $(0.8 \%)$ medium without glucose. Two weeks later, colonies of about 2 to $3 \mathrm{~mm}$ in diameter were transferred to $\mathrm{N} 6$ medium supplemented with $5 \%$ sucrose, $0.2 \mathrm{mg} / \ell$ indole-acetic acid, $1 \mathrm{mg} / \ell$ kinetin and $1 \%$ agarose for
Hanahikari

5 MT sensitive

Regenerable
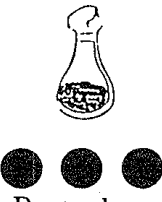

Protoplast

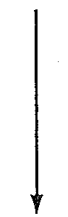

No colony

formation
Sasanishiki (SAR-3)

5MT resistance

Non-regenerable
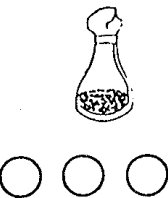

Protoplast

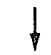

Cell fusion

via dextran

method

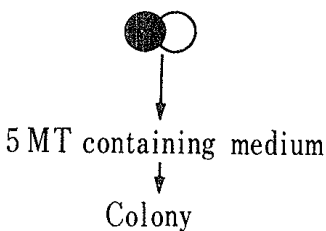

Colony Colony

formation formation

Regeneration medium

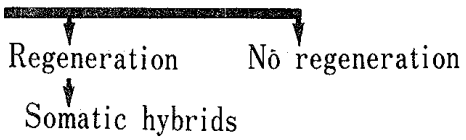

Fig. 1. Selection scheme for somatic hybrids between SAR-3 and Hanahikari. Somatic hybrids were selected by using 5-metyltryptophan (5MT) and then by regeneration medium.

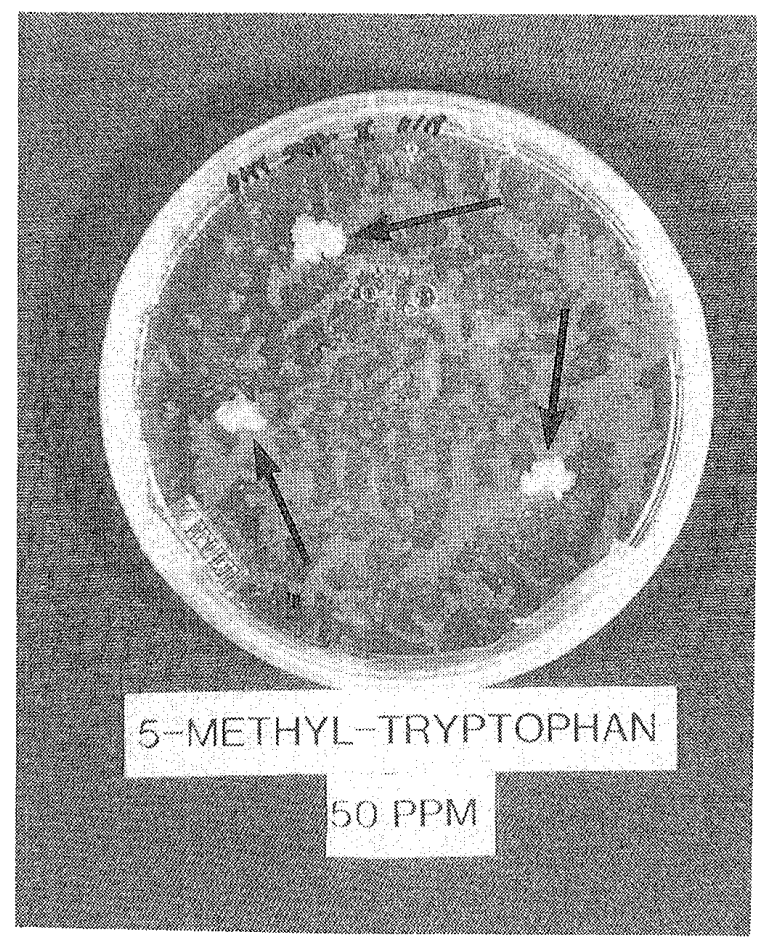

Fig. 2. There 5MT resistant calli developed on agar medium containing $50 \mathrm{ppm} 5 \mathrm{MT}$ at one month after plating. Arrows indicate $5 \mathrm{MT}$ resistant calli. 
plant regeneration. The selection procedure for somatic hybrids is shown in Fig. 1. The suspension and protoplast cultures were grown in the dark and plant regeneration was performed under fluorescent light (3000lux) at $25^{\circ} \mathrm{C}$.

\section{Results and Discussion}

By plating cell suspensions on the 5MT (50 ppm) agar medium, three resistant colonies were selected (Fig. 2). The frequency of resistant colonies was about $5 \times 10^{-7}$ per cell. These three resistant cell lines were designated as SAR-1, -2 and -3 , and used to investigate whether 5MT resistance is stable or not. After 2 months of culture in AA medium without 5MT, SAR-1 and -3 were still resistant to 5MT but SAR-2 lost its resistance (Fig. 3). SAR-1 and SAR-3 could grow at $200 \mathrm{ppm}$ of 5MT, whereas growth of the unselected cell (SAS) was completely inhibited even at $50 \mathrm{ppm}$. SAR-3 has been showing resistance even when grown without 5MT for more than one year (Fig. 5). Therefore, it is surely expected that they are stable 5MT-resistant cell lines.

Table 1 shows the free amino acid contents of both SAR-3 and SAS. 5MT resistant cell line, SAR-3, contained 50 times more than the normal level of free tryptophan as pointed out by WAKASA and WIDHoLm (1987). Resistance in SAR-3 is considered to be due to the accumulation of high levels of free tryptophan. The contents of the other free amino acids in SAR-3 were 1.5 to 5 times higher than those of SAS. The total amount of free amino acids in SAR-3 also increased about 2 times more than that of SAS.

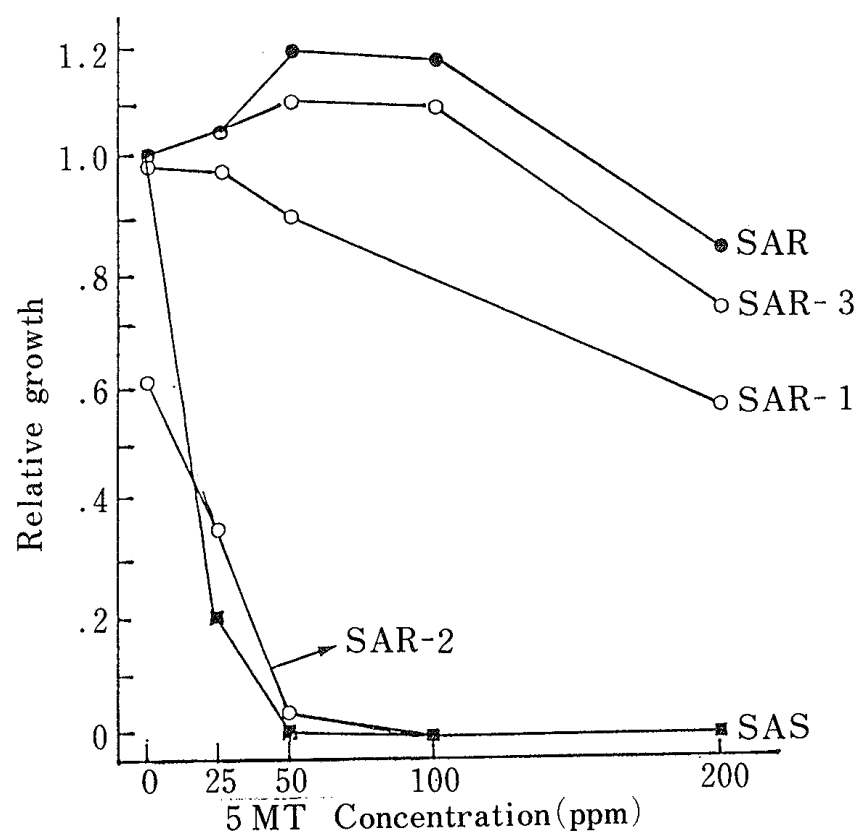

Fig. 3. Stability of selected cell lines resistant to 5MT. 5MT resistance was determined after 2 months culture with or without $50 \mathrm{ppm}$ 5MT. SAR: SAR-3 cultured with 5MT continuously. SA (R1, R2, R3): Resistant cell lines cultured without 5MT for 2 months. SAS: unselected cell.

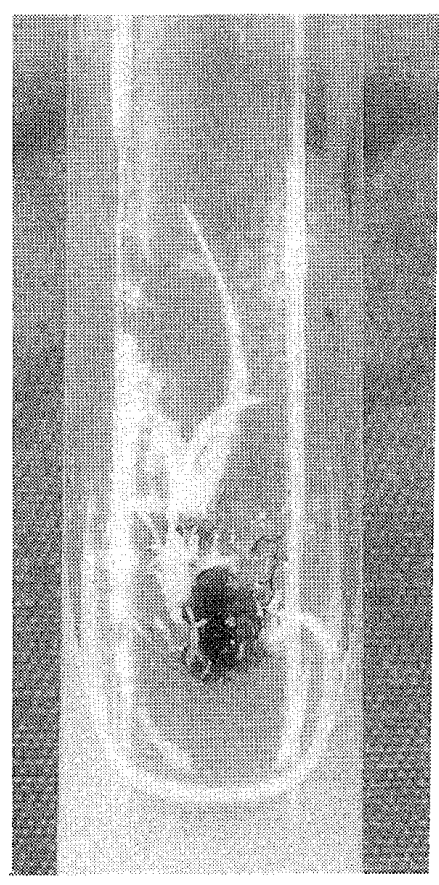

Fig. 4. Plant regeneration from calli selected from fusion treated protoplasts. 


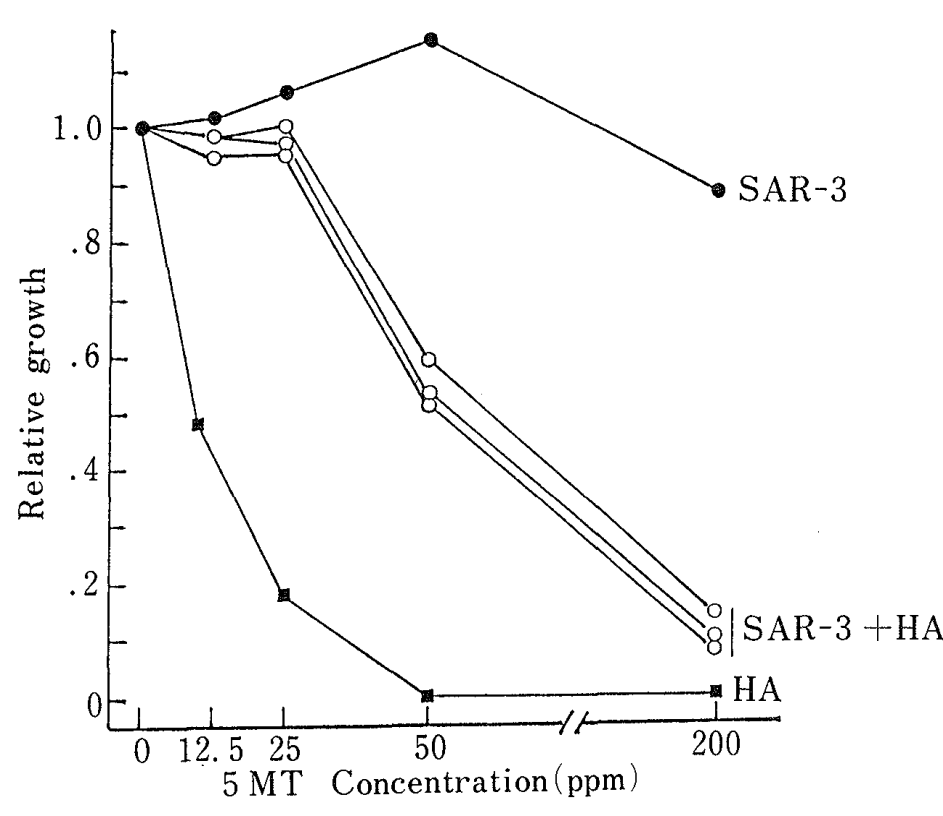

Fig. 5. Effect of 5MT on cell growth expressed as packed cell volume as compared to that in AA midium. The packed cell volume was determined after 10 days. SAR-3: 5MT resistant cell line after culture of 15 months without $5 \mathrm{MT}$. HA: Hanahikari. SAR-3 + HA: somatic hybrid.

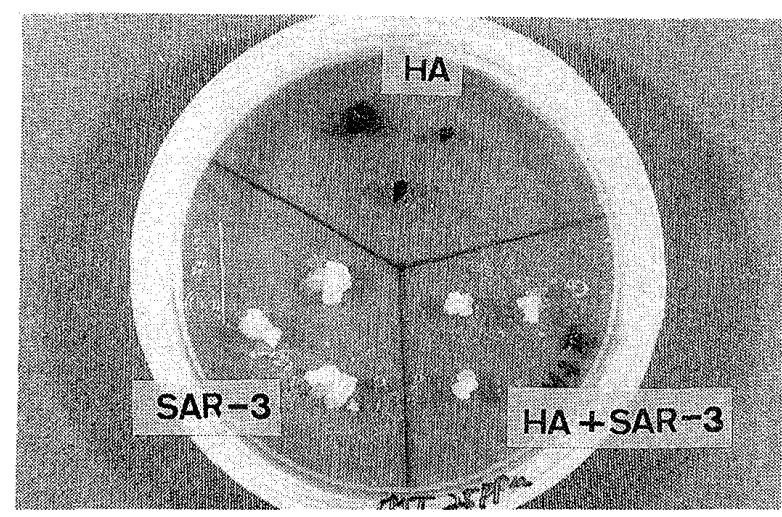

Fig. 6. Effect of 5MT on callus growth of SAR-3, $\mathrm{HA}$ and SAR-3 + HA at one month after culture.
Attempts to regenerate plants from SAR-3 using plant regeneration medium have been unsuccessful. Therefore, it is assumed that SAR-3 has lost plant regeneration capacity.

Protoplast fusion and slection of somatic hybrids between SAR-3 and HA were carried out according to the scheme in Fig. 1. Fused protoplasts could not be identified because it was impossible to distinguish SAR-3 from $\mathrm{HA}$ in morphology of isolated protoplasts.

From the preexamintion for culture of SAR-3 protoplasts, it was found that colony formation was greatly influenced by both $5 \mathrm{MT}$ concentration and the time of addition of selection medium (Table 2). In the present experiemnts, the fusion-treated protoplasts were cultured in $\mathrm{B} 5$ medium without $5 \mathrm{MT}$ for 5 to 6 weeks, then transferred to selection medium containing 25ppm 5MT, which caused death of HA protoplasts. After about 2 weeks, 570 colonies (more than $2 \mathrm{~mm}$ in diameter) were recovered from $2 \times 10^{5}$ protoplasts. These colonies were transferred to regeneration medium and 3 albino plants differentiated (Fig. 4). Since HA protoplasts could not develop to colonies and SAR-3 colonies did not produce any orgns under the present experiemntal conditions (Table 3), these albino plants are highly suspected to be the somatic hybrids between SAR-3 and HA.

In order to test 5MT resistance of the somatic hybrids, the callus induced from the roots was incubated in AA liquid medium with a range of 5MT concentrations. The results showed that the levels of resistance of the hybrid callus was intermediate of that of parents (Fig. 5 and 6).

From the above results, the 5MT resistance of SAR-3 can be considered to be stably inherited to the hybrids as reported in Nicotiana (White and Vasil 1979), Daucus (Kameya et 
Table 2. The effect of $5 \mathrm{MT}$ concentration and time of applying selection medium on the growth of SAR-3 protoplast culture

\begin{tabular}{|c|c|c|c|c|c|c|}
\hline $\begin{array}{l}\text { Culture period (weeks) } \\
\text { before } 5 \mathrm{MT} \text { addition }\end{array}$ & $\begin{array}{l}\text { Liquid media for protoplast } \\
\text { culture }\end{array}$ & 0 & $\begin{array}{c}5 \mathrm{MT} \\
5\end{array}$ & $\begin{array}{c}\text { entra } \\
10\end{array}$ & $\begin{array}{l}(\mathrm{mg} / \ell) \\
25\end{array}$ & 50 \\
\hline \multirow{3}{*}{$2 \mathrm{C}$} & $\mathrm{NO}_{3}$ & + & - & - & - & - \\
\hline & B5 & ++ & - & - & - & - \\
\hline & $\mathrm{AA}$ & + & + & - & - & - \\
\hline \multirow{3}{*}{$3-4 \quad C$} & $\mathrm{NO}_{3}$ & ++ & - & - & - & - \\
\hline & B5 & + & - & - & - & - \\
\hline & $\mathrm{AA}$ & + & + & + & - & - \\
\hline \multirow{3}{*}{$5-6 \mathrm{C}$} & $\mathrm{NO}_{3}$ & ++ & ++ & ++ & + & + \\
\hline & B5 & ++ & ++ & ++ & ++ & + \\
\hline & $\mathrm{AA}$ & + & + & + & + & + \\
\hline
\end{tabular}

++ : Vigorous growth, +: A little growth, $-:$ No growth

$\mathrm{NO}_{3}$ : B5 medium without $\left(\mathrm{NH}_{4}\right)_{2} \mathrm{SO}_{4}$ was supplemented with $2.95 \mathrm{~g} / \ell \mathrm{KCl}$.

AA: Toriyama et al. 1985

B\%: Gamborg et al. 1968

Table 3. Regeneration frequency of colonies obtained from selection medium (B5 medium containing $25 \mathrm{ppm} 5 \mathrm{MT}$ )

\begin{tabular}{lcrccc}
\hline \hline Cultivar & Repetition & $\begin{array}{l}\text { Number of colonies } \\
\text { transplanted to } \\
\text { regeneration } \\
\text { medium }\end{array}$ & $\begin{array}{l}\text { Number of colonies produced } \\
\text { Green plant Albino plant }\end{array}$ & Root \\
\hline SAR-3 & 2 & 300 & 0 & 0 & 0 \\
HA & 2 & 0 & 0 & 0 & 0 \\
SAR-3 + HA & 5 & 570 & 0 & 3 & 5 \\
\hline
\end{tabular}

SAR-3: Sasanishiki (5MT resistant calli)

HA: Hanahikari (5MT sensitive calli)

1981) and Sinapis (Toriyama et al. 1987). Our results also demonstrate that the combination of 5MT resistance and plant regeneration capacity is an effective selection marker or somatic hybridization in rice plants.

\section{Acknowledgement}

We give thanks to Mr. Kiyotaka Hatakeda, the Government Industrial Research Institute, Tohoku, for his assistance in analysing amino acids. We are also greatful to Professor Hiroshi Suge, Dr. Kinya Toriyama and Mr. Seiichi Toki for their useful advice.

\section{Literature Cited}

AbDullah, R., E.C. CoOKIng and J. A. ThOMPSON 1986. Efficient plant regeneration from rice protoplasts through somatic embryogenesis. BIOTECHNOLOGY 4:1087 1090.

Chu, C. C., C. C. Wangm, K. C. Yin, C. Y. Cchu and F. Y. Bi (1975). Establishment of an efficient 
medium for anther culture of rice through comparative experiments on the nitrogen sources. Sci. Sin. 18:659 668.

Gamborg, O. L., R. A. Miller and K. OJima 1968. Nutrient requirements of suspension cultures of soybean root cells. Exp. Cell Res. 50:151 158 .

Harm, C. T., I. K. Potrykus and J.M. Widholm 1981. Complemention and dominant expression of amino acid analogue resistance markers in somatic hybrid colonies from Daucus carota after protoplast fusion. Z. Pflanzenphysiol. 101:377 390.

Harms, C. T., J. J. OerTl and J. M. WIDHOLM 1982. Characterization and dominant expression of amino acid analogue resistance markers in somatic hybrid cell lines of Daucus carota L., Z. Pflanzenphysiol. $106: 239 \sim 249$.

Horn, M. E., T. Kameya, J. E. Brotherton and J. M. Widholm 1983. The use of amino acid analog resistance and plant regeneration ability to select somatic hybrids between Nicotiana tabacum and N. glutinosa. Mol. Gen. Genet. 192:235 240.

Kameya, T., M. E. Horn and J.M. Widholm 1981. Hybrid shoot formation from fused Daucus carota and D. capillifolius protoplasts. Z. Pflanzenphysiol. 104:459 466.

1983. Studies on plant cell fusion by dextran: Effects of $\mathrm{pH}$, inorganic salts and electrical stimulus. Cytologia $\mathbf{4 8}: 873 \sim 879$.

Toriyama, K. and K. Hinata 1985. Cell suspension and protoplast culture in rice. Plant Sci. $41: 179 \sim 183$.

- K., T. Kameya and K. Hinata 1987. Selection of a universal hybridizer in Sinapis turgida Del. and regeneration of plantlets from somatic hybrids with Brassica species. Planta 170:308 313.

WAKASA, K. and J. M. WIDHOLM 1987. A 5-methyltryptophan resistant rice mutant, MTR1, selected in tissue culture. Theor. Appl. Genet. 74:49 54.

White, D. W. R. and I. K. VASIL 1979. Use of amino acid analogue-resistant cell lines for selection of Nicotiana sylvestris somatic cell hybrids. Theor. Appl. Genet. 55:107 112.

\title{
イネの細胞融合における 5 ーメチルトリプトファン耐性細胞株の利用
}

\author{
李 孝淵, 龟谷寿昭 \\ （東北大学遺伝生態研究センター） \\ (仙台市片平 2 丁目 $1-1$, T 980)
}

5ーメチルトリプトファン（5MT）耐性細胞株をイネ（品種，ササニシキ）の葯培養由来の懸濁培養細胞から， $50 \mathrm{ppm} の 5 \mathrm{MT}$ 含む液体培地及び寒天培地で選抜したところ，3 系統の細胞株 (SAR－1，2，3)が得られた。

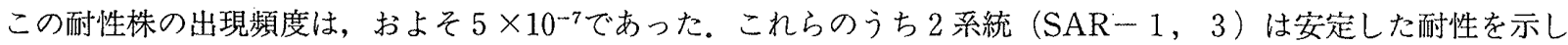
たが，1系統（SAR-2）は，二ヶ月間， $5 \mathrm{MT}$ 含まない培地で培養したところ耐性を消失した，安定した耐性 を示したSAR－3の遊離アミノ酸含量を分析したところ，トリプトファンが $5 \mathrm{MT}$ で選抜しなかった親株より，50 倍増加していることがわかった。この SAR－3 株からの植物再分化を試みたが, 成功せず, それ故, この株は, 長 期培盖のため，再分化能力を失ったものと推定した。

$\mathrm{SAR}$ - 3 株の $5 \mathrm{MT}$ 而性形質を植物体に導入するため, 再分化能力があり，5 MT 感受性の細胞株(ハナ七カリ) との細胞融合を行った，両プラトプラストをデキストラン溶液中で混合し，融合処理を行った。コロニーの直径が $200 \mu \mathrm{m}$ ぐらいになるまで $5 \mathrm{MT}$ 無添加培地で培荃した。 その後， $5 \mathrm{MT} 25 \mathrm{ppm}$ を含む選抜培地で 2 週間培養し， 盛んに増殖してきたコロニーを選び, 再分化培地で培盖したところ, およそ $2 \times 10^{5}$ 個のプロトプラストから, 3 個 のアルビノ植物が得られた。これらの植物からカルスを作出し， $5 \mathrm{MT}$ 耐性を調查したところ，SAR一 3 と八ナヒ カリの中間型を示した。本箺験の对照として用いた SAR-3 は再分化せず，八ナヒカリにおいては，細胞分裂はほ とんど観察されず，コロニー形成には到らなかったので，得られたアルビノ個体は雑種であると推定された。

本実験の結果は他植物 (Nicotiana, Dacus, Sinapis) で報告されているように，5MT 耐性と再分化能のマーカー がイネの細胞融合においても有効であることを示している. 